\title{
PENGARUH MOTIVASI DAN KEPUASAN KERJA TERHADAP DISIPLIN KERJA DAN DAMPAKNYA TERHADAP KINERJA PEGAWAI DINAS PERTANIAN DAN KETAHANAN PANGAN KOTA BANJAR
}

\author{
Maman Sulaeman ${ }^{1}$ \\ Sri Herdiani ${ }^{2}$ \\ ${ }^{1}$. Dosen Politeknik Triguna Tasikmalaya \\ ${ }^{2}$. PNS di Dinas Pertanian dan Ketahanan Pangan Kota Banjar
}

\begin{abstract}
Abstrak
Tingginya tingkat penyimpangan yang terjadi di instansi-instansi pemerintah baik dalam bentuk penyimpangan kekuasaan, tanggung jawab maupun kepercayaan telah menunjukkan betapa rendahnya kinerja terutama di dalam mematuhi peraturan-peraturan kerja dan norma-norma sosial yang berlaku dalam melaksanakan tugas yang diberikan. Tujuan penelitian ini untuk menganalisis pengaruh motivasi dan kepuasan kerja terhadap disiplin kerja dan dampaknya terhadap kinerja pegawai Dinas Pertanian Dan Ketahanan Pangan Kota Banjar. Penelitian ini dilaksanakan dengan menggunakan path analisis. Populasi dalam penelitian ini adalah seluruh pegawai Dinas Pertanian dan Ketahanan Pangan Kota Banjar yang berdasarkan data kepegawaian sebanyak 62 orang. Teknik pengambilan sampel secara sensus yaitu sebanyak 62 orang. Hasil penelitian menunjukkan motivasi berpengaruh signifikan terhadap kinerja pegawai pada dimensi kebutuhan dan harapan. Kepuasan pegawai berpengaruh signifikan terhadap kinerja pada dimensi pekerjaan itu sendiri, upah, peluang promosi, pengawasan, kelompok kerja, kondisi kerja. Disiplin kerja berpengaruh signifikan terhadap kinerja pada dimensi frekuensi kehadiran, tingkat kewaspadaan, ketaatan pada standar kerja, ketaatan pada peraturan kerja dan etika kerja. Kinerja pegawai dipengaruhi oleh motivasi, kepuasan dan disiplin.
\end{abstract}

Kata Kunci: Motivasi, Kepuasan, Disiplin, Kinerja

\begin{abstract}
The high level of irregularities that occur in establishments-government agencies in the form of deviation authority, responsibility or the trust has shown just how low performance especially in complying with regulations and social norms that apply in carrying out the task given. The purpose of this research was to analyze the influence of motivation and job satisfaction against the discipline of work and its impact on the performance of the employees of the Department of Agriculture And food security the town of Banjar. This research was carried out by using path analysis. The population in this study are all employees of the Department of agriculture and food security based on Banjar staffing as many as 62 people. The technique of sampling in the census that is as many as 62 people. The results showed a significant effect of motivation on performance clerk on the dimensions of your needs and expectations. Employee satisfaction the significant effect on performance on the dimensions of the work itself, wages, promotion opportunities, supervision, group work, working conditions. Influential work discipline significantly to performance in the presence of frequency dimensions, level of alertness, adherence to standards, adherence to the rules of work and work ethic. The performance of the employees affected by the motivation, satisfaction and discipline.
\end{abstract}

Keywords: Motivation, Satisfaction, Discipline, Performance 


\section{PENDAHULUAN}

Pegawai pada sebuah organisasi pemerintah, dituntut untuk dapat memberikan pelayanan terbaik atau pelayanan prima sesuai dengan fungsi organisasinya. Kualitas pelayanan pegawai yang ditunjuk melalui kinerjanya dapat diukur melalui penilaian yang didasarkan pada kemampuannya, untuk menjabarkan uraian tugas (job description) ke dalam perilaku pelayanan kepada masyarakat dengan baik dan memuaskan sesuai standar pelayanan. Penilaian kinerja pegawai secara konseptual dan empiris juga berhubungan erat dengan tugas pokok dan fungsi unit kerja, uraian tugas dan standar kinerja

Tingginya tingkat penyimpangan yang terjadi di instansi-instansi pemerintah baik dalam bentuk penyimpangan kekuasaan, tanggung jawab maupun kepercayaan telah menunjukkan betapa rendahnya kinerja terutama di dalam mematuhi peraturan-peraturan kerja dan normanorma sosial yang berlaku dalam melaksanakan tugas yang diberikan. Fenomena yang terjadi di lingkungan Dinas Pertanian dan Ketahanan Pangan Kota Banjar saat ini adalah adanya pelanggaran disiplin yang dilakukan sebagai pegawai terhadap aturan jam kerja yaitu pasca apel pagi, beberapa pegawai tidak langsung melaksanakan tugasnya masing-masing menuju ruangan kerja. Akan tetapi melakukan kegiatan atau aktivitas dengan mengobrol dan berjemur di halaman kantor, sehingga sudah jelas mengurangi jam kerja yang sebenarnya seharusnya dilaksanakan sepanjang jam kerja berlangsung mulai pukul 08.00 WIB sampai dengan 14.45 WIB. Disamping pelanggaran lainnya yang dilakukan oleh beberapa pegawai lainnya dengan terlambatnya kehadiran mengikuti apel pagi yang seharusnya dilaksanakan dan diikuti setiap hari selama 5 (lima) hari kerja dalam satu minggu.

Selain hal tersebut di atas kondisi pegawai di lingkungan Dinas Pertanian dan Ketahanan Pangan Kota Banjar terlihat masih rendahnya disiplin pegawai pada kantor tersebut pada situasi kerja berikut: (1) Tingginya angka kemangkiran (absensi) pegawai; (2) Sering terlambatnya pegawai masuk kantor atau pulang lebih cepat dari jam yang sudah ditentukan; (3) Menurunnya semangat, gairah kerja, dan inisiatif para pegawai dalam melaksanakan pekerjaan; (4) Penyelesaian pekerjaan yang lambat, karena pegawai lebih senang mengobrol dari pada bekerja; (5) Rendahnya rasa kepedulian pegawai terhadap pencapaian tujuan organisasi;
Rendahnya rasa tanggung jawab para pegawai untuk melaksanakan tugas dengan sebaikbaiknya.

Peningkatan disiplin kerja menjadi bagian yang penting dalam sumber daya manusia, sebagai faktor penting dalam kinerja karyawan itu sendiri. Disiplin kerja adalah suatu alat yang digunakan para manajer untuk berkomunikasi dengan karyawan agar mereka bersedia untuk mengubah suatu perilaku serta sebagai suatu upaya untuk meningkatkan kesadaran dan kesediaan seseorang mentaati norma-norma sosial yang berlaku sehingga menghasilkan kinerja yang baik. Kinerja itu berarti prestasi kerja, pelaksanaan kerja, pencapaian kerja atau hasil dari pekerjaan. Berbicara mengenai kinerja erat kaitannya dengan cara mengadakan penilaian terhadap pekerjaan seseorang sehingga perlu ditetapkan standar kerja. Kinerja dapat dinilai dari apa yang dilakukan seorang karyawan dalam kerjanya, sehingga dapat disimpulkan bahwa kinerja adalah prestasi kerja atau hasil kerja (output) baik kualitas atau kuantitas yang dicapai individu persatuan waktu dalam melaksanakan tugas kerjanya sesuai dengan tanggung jawab yang diberikan.

\section{TINJAUAN TEORI \\ Motivasi}

Motivasi berasal dari kata latin "movere" yang berarti dorongan atau daya penggerak "motivasi ini hanya diberikan kepada manusia khususnya kepada para bawahan atau pengikut, jadi motivasi mempersoalkan bagaimana caranya mendorong gairah kerja bawahan, agar mereka mau bekerja keras dengan memberikan semua kemampuan dan keterampilannya untuk mewujudkan tujuan yaitu mencapai hasil kerja yang optimal. Sedangkan motivasi merupakan suatu fungsi dari berbagai macam variabel yang saling mempengaruhi, ia merupakan suatu proses yang terjadi dalam diri manusia atau suatu proses psikologis.

\section{Kepuasan}

Setiap karyawan yang bekerja dalam suatu perusahaan mempunyai tujuan dan harapan-harapan untuk memenuhi kebutuhan hidup sehari-hari. Apabila kebutuhan karyawan tersebut terpenuhi berarti pekerjaan yang digeluti dapat memberikan rasa kepuasan. Namun sebaliknya jika kebutuhannya tidak terpenuhi dengan baik, maka karyawan tersebut merasakan pekerjaannya tidak memberikan rasa kepuasaan. 
Pada dasarnya kepuasan kerja merupakan hal yang bersifat individu. Setiap individu akan memilliki tingkat kepuasan yang berbeda-beda sesuai dengan sistem ilai-nilai yang berlaku pada dirinya. Ini disebabnya karena adanya perbedaan pada masing-masing individu. Semakin banyak aspek-aspek dalam pekerjaan yang sesuai dengan keinginan individu tersebut, maka semakin tinggi tingkat kepuasan kerja yang dirasakannya dan sebaliknya.

Disiplin

Menurut Hasibuan

(2008:193),

"Kedisiplinan adalah kesadaran dan kesediaan seseorang mentaati semua peraturan perusahaan dan norma-norma sosila yang berlaku". Jadi kedisiplinan dapat diartikan jika karyawan datang dan pulang tepat pada waktunya, mengerjakan semua tugasnya dengan sebaik mungkin, mematuhi peraturan perusahaan dan normanorma sosial yang berlaku

\section{Kinerja}

Mathis dan Jackson (2006:78) menyatakan bahwa :" kinerja pada dasarnya adalah apa yang dilakukan atau tidak dilakukan karyawan. Kinerja karyawan adalah yang mempengaruhi seberapa banyak mereka memberi kontribusi kepada organisasi, dalam hal antara lain: kuantitas output, kualitas output, jangka waktu output, kehadiran di tempat kerja dan sikap kooperatif".

\section{Metode Penelitian}

Penelitian ini akan dilaksanakan dengan menggunakan metode deskriptif analisis dengan teknik survey. Pada penelitian ini peneliti menganalisis Pengaruh Motivasi dan Kepuasan terhadap Disiplin dan Kinerja Pegawai Dinas Pertanian dan Ketahanan Pangan Kota Banjar.

Populasi pada penelitian ini adalah seluruh pegawai Dinas Pertanian dan Ketahanan Pangan Kota Banjar yang berdasarkan data kepegawaian sebanyak 62 orang. Menurut Arikunto (2009:170) syarat sampel adalah harus memewakili dan dapat dipertanggungjawabkan, semakin banyak sampel semakin baik hasil penelitian. Teknik sampling menggunakan sampling jenuh (sensus) yaitu seluruh anggota populasi dijadikan sampel penelitian. Sehingga jumlah sampel pada penelitian ini sebanyak 62 orang.
Hasil Penelitian

Pengaruh Motivasi dan Kepuasan terhadap Disiplin Pegawai baik secara parsial ataupun simultan

\begin{tabular}{|c|c|c|c|c|c|}
\hline \multirow{3}{*}{ Model } & \multicolumn{4}{|c|}{ Coefficients $^{\mathrm{a}}$} & \multirow{3}{*}{ Sig. } \\
\hline & \multicolumn{2}{|c|}{$\begin{array}{l}\text { Unstandardized } \\
\text { Coefficients }\end{array}$} & $\begin{array}{c}\text { Standar } \\
\text { dized }\end{array}$ & \multirow[t]{2}{*}{$\mathrm{t}$} & \\
\hline & B & $\begin{array}{c}\text { Std. } \\
\text { Error }\end{array}$ & Beta & & \\
\hline (Constant) & 3.012 & 4.834 & & .623 & .536 \\
\hline 1 Motivasi & .468 & .134 & .410 & 3.506 & .001 \\
\hline Kepuasan & .346 & .167 & .243 & 2.073 & .043 \\
\hline
\end{tabular}

a. Dependent Variable: Disiplin

Secara lengkap hubungan kausalitas antara variabel motivasi dan kepuasan terhadap disiplin pegawai dapat digambarkan sebagai berikut:

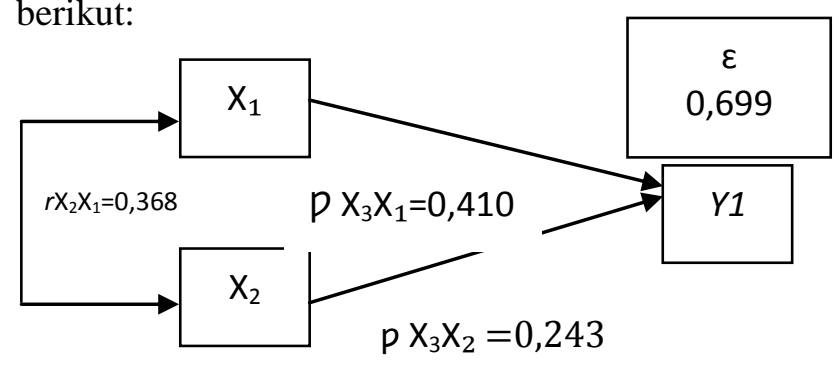

Dari Gambar di atas, dapat diketahui nilai koefisien jalur antara variabel independen dan dependen. Nilai koefisien jalur variabel motivasi $\left(\mathrm{X}_{1}\right)$ dengan disiplin $\left(\rho \mathrm{Y} 1 \mathrm{X}_{1}\right)$ sebesar 0,410 . Nilai koefisien jalur variabel kepuasan $\left(\mathrm{X}_{2}\right)$ dengan disiplin pegawai $\left(\rho \mathrm{Y}_{1} \mathrm{X}_{2}\right)$ sebesar 0,243 serta epsilon sebesar 0,699 . Berdasarkan nilai koefisien jalur tersebut secara rinciannya dapat diuraikan sebagai berikut:

\begin{tabular}{|c|c|}
\hline Keterangan & Nilai \\
\hline $\begin{array}{lccc}\text { Pengaruh } & \mathrm{X}_{1} \text { terhadap } \\
\text { langsung } & \left(\mathrm{p} Y 1 \mathrm{X}_{1}\right)^{2} & & \text { secara } \\
\end{array}$ & 0,168 \\
\hline $\begin{array}{l}\text { Pengaruh } X_{1} \text { terhadap Y1 melalui } X_{2} \\
\text { pY1X }{ }_{1 . X 1 X 2 .} \text { pY1X }_{2}\end{array}$ & 0,037 \\
\hline Pengaruh Total $\mathrm{X}_{1}$ terhadap Y1 & 0,205 \\
\hline $\begin{array}{l}\text { Pengaruh } \mathrm{X}_{2} \text { terhadap } \mathrm{Y} 1 \text { secara } \\
\text { langsung }\left(\mathrm{pY} 1 \mathrm{x}_{2}\right)^{2}\end{array}$ & 0,059 \\
\hline $\begin{array}{l}\text { Pengaruh } \mathrm{X}_{2} \text { terhadap Y1 melalui } \mathrm{X}_{1} \\
\text { pY1X } \mathrm{X}_{1 \mathrm{X} 1 \mathrm{X} 2 .} \text { pY1X }\end{array}$ & 0,037 \\
\hline Pengaruh Total $\mathbf{X}_{2}$ terhadap Y1 & $\mathbf{0 , 0 9 6}$ \\
\hline $\begin{array}{l}\text { Pengaruh } X_{1}, X_{2} \text { secara bersama- } \\
\text { sama terhadap Y1 }\end{array}$ & $\mathbf{0 , 3 0 1}$ \\
\hline Pengaruh Variabel lain & $\mathbf{0 , 6 9 9}$ \\
\hline
\end{tabular}


Berdasarkan Tabel diatas terlihat bahwa : Pengaruh motivasi terhadap disiplin sebesar 0,205 atau 20,50\% dan pengaruh kepuasan terhadap disiplin sebesar 0,096 atau 9,6\%.

Pengaruh Motivasi dan Kepuasan terhadap Kinerja Pegawai baik secara parsial ataupun simultan

Hasil perhitungan SPSS diperoleh data sebagai berikut:

\section{Coefficients $^{\mathrm{a}}$}

\begin{tabular}{|c|c|c|c|c|}
\hline \multirow[t]{2}{*}{ Model } & \multicolumn{2}{|c|}{$\begin{array}{l}\text { Unstandardized } \\
\text { Coefficients }\end{array}$} & \multirow{2}{*}{\begin{tabular}{|c}
$\begin{array}{c}\text { Standard } \\
\text { ized } \\
\text { Coeffici } \\
\text { ents }\end{array}$ \\
Beta
\end{tabular}} & \multirow[t]{2}{*}{$\mathrm{t}$} \\
\hline & B & $\begin{array}{l}\text { Std. } \\
\text { Error }\end{array}$ & & \\
\hline (Constant) & 20.948 & 2.862 & & 7.319 \\
\hline Motivasi & .207 & .079 & .309 & 2.622 \\
\hline Kepuasan & .285 & .099 & .341 & 2.886 \\
\hline
\end{tabular}

a. Dependent Variable: Kinerja

Secara lengkap hubungan kausalitas antara variabel motivasi dan kepuasan terhadap kinerja pegawai dapat digambarkan sebagai berikut:

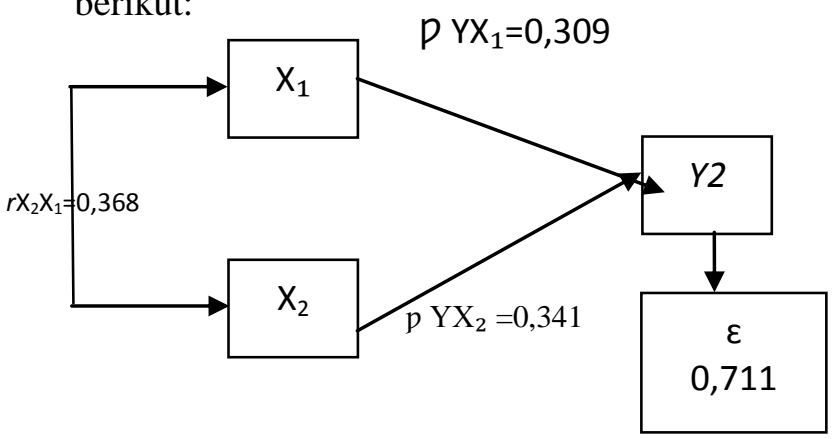

\begin{tabular}{|c|c|}
\hline Keterangan & Nilai \\
\hline $\begin{array}{lcccc}\begin{array}{l}\text { Pengaruh } \\
\text { langsung }\end{array} & \mathrm{X}_{1} \quad \text { terhadap } & \mathrm{Y} & \text { secara } \\
\left(\mathrm{pY} \mathrm{YX}_{1}\right)^{2} & & \end{array}$ & 0,095 \\
\hline $\begin{array}{l}\text { Pengaruh } \mathrm{X}_{1} \text { terhadap } \mathrm{Y} \text { melalui } \mathrm{X}_{2} \\
\text { pY1X } \mathrm{X}_{1 \mathrm{X} 1 \mathrm{X} 2 . \mathrm{pYX}}\end{array}$ & 0,039 \\
\hline Pengaruh Total $\mathbf{X}_{1}$ terhadap $\mathbf{Y}$ & $\mathbf{0 , 1 3 4}$ \\
\hline $\begin{array}{l}\text { Pengaruh } \mathrm{X}_{2} \text { terhadap } \mathrm{Y} \text { secara } \\
\text { langsung }\left(\mathrm{pY}_{\left.\mathrm{x}_{2}\right)^{2}}\right.\end{array}$ & 0,116 \\
\hline $\begin{array}{l}\text { Pengaruh } \mathrm{X}_{2} \text { terhadap Y melalui } \mathrm{X}_{1} \\
\text { pYX } \\
\text { 1.X1X2. }_{\text {pYX }}\end{array}$ & 0,039 \\
\hline Pengaruh Total $\mathrm{X}_{2}$ terhadap $\mathrm{Y}$ & $\mathbf{0 , 1 5 5}$ \\
\hline $\begin{array}{l}\text { Pengaruh } X_{1}, X_{2} \text { secara bersama- } \\
\text { sama terhadap Y }\end{array}$ & $\mathbf{0 , 2 8 9}$ \\
\hline Pengaruh Variabel lain & $\mathbf{0 , 7 1 1}$ \\
\hline
\end{tabular}

Berdasarkan Tabel 4.55 diatas terlihat bahwa : Pengaruh motivasi terhadap kinerja sebesar 0,134 atau $13,40 \%$ dan pengaruh kepuasan terhadap kinerja sebesar 0,155 atau $15,5 \%$.

\section{Pengaruh Disiplin Terhadap Kinerja Pegawai}

Hasil pengolahan data dapat diketahui pengaruh disiplin terhadap kinerja pegawai yang dapat dilihat pada Tabel berikut ini:

Model Summary

\begin{tabular}{|l|r|r|r|r|}
\hline Model & $\mathrm{R}$ & $\begin{array}{c}\mathrm{R} \\
\text { Square }\end{array}$ & $\begin{array}{c}\text { Adjusted } \\
\text { R Square }\end{array}$ & $\begin{array}{c}\text { Std. Error of } \\
\text { the Estimate }\end{array}$ \\
\hline 1 & $.484^{\mathrm{a}}$ & .234 & .221 & 2.47482 \\
\hline
\end{tabular}

a. Predictors: (Constant), Disiplin

$.00 \$$ rdasarkan Tabel di atas terlihat bahwa disiplin mempunyai pengaruh terhadap kinerja. Hal ini ditunjukkan oleh $r$ hitung sebesar 0,484 dar 005 efisien determinasi sebesar 23,4\%. Berdasarkan hasil perhitungan, diperoleh Sig $=$ 0,000 sedangkan tingkat kesalahan sebesar 5\% atau $(\alpha=0,05)$ sehingga $P$ value $<\alpha$ atau $0,000<$ 0,05 maka $\mathrm{H}_{\mathrm{o}}$ ditolak dan $\mathrm{H}_{\mathrm{a}}$ diterima sehingga hipotesis diterima. Artinya secara simultan terdapat pengaruh yang signifikan dari disiplin terhadap kinerja pegawai Dinas Pertanian Dan Ketahanan Pangan Kota Banjar, sehingga hipotesis teruji kebenarannya.

\section{Pengaruh Motivasi, Kepuasan terhadap Disiplin dan Kinerja Pegawai}

\section{Coefficients $^{\mathrm{a}}$}

\begin{tabular}{|c|c|c|c|c|c|}
\hline \multirow[t]{2}{*}{ Model } & \multicolumn{2}{|c|}{$\begin{array}{l}\text { Unstandardized } \\
\text { Coefficients }\end{array}$} & \multirow{2}{*}{\begin{tabular}{|c}
$\begin{array}{c}\text { Standard } \\
\text { ized } \\
\text { Coeffici } \\
\text { ents }\end{array}$ \\
Beta
\end{tabular}} & \multirow[t]{2}{*}{$\mathrm{t}$} & \multirow[t]{2}{*}{ Sig. } \\
\hline & B & $\begin{array}{l}\text { Std. } \\
\text { Error }\end{array}$ & & & \\
\hline (Constant) & 20.454 & 2.783 & & 7.350 & .000 \\
\hline Kepuasan & .229 & .099 & .273 & 2.304 & .025 \\
\hline Motivasi & .131 & .084 & .195 & 1.750 & .027 \\
\hline Disiplin & .164 & .075 & .279 & 2.194 & .032 \\
\hline
\end{tabular}

a. Dependent Variable: Kinerja

Berdasarkan data pada Tabel di atas dapat digambarkan pengaruh motivasi (X1) dan kepuasan (X2) terhadap disiplin (Y1) dan dampaknya terhadap kinerja pegawai (Y) sebagai berikut : 


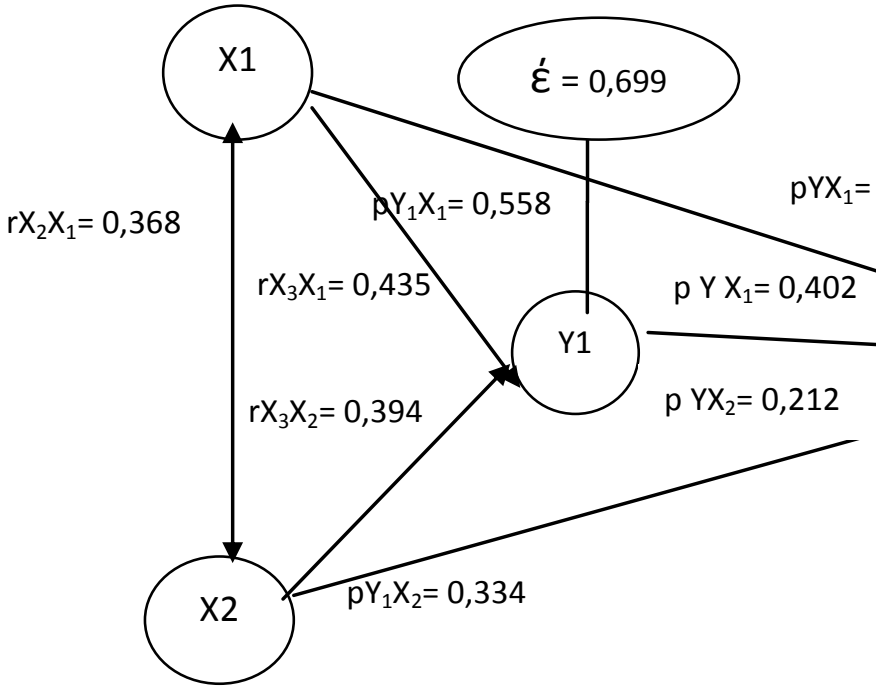

Berdasarkan Gambar 4.3 di atas dapat dibuat ringkasan hasil estimasi parameter model sebagai berikut:

\begin{tabular}{|c|c|c|c|c|}
\hline Model & $\begin{array}{c}\text { Koefisien } \\
\text { Jalur }\end{array}$ & $\begin{array}{c}\mathrm{t} \\
\text { hitung }\end{array}$ & $\rho$ & $\mathbf{r}^{2}$ \\
\hline \multicolumn{5}{|c|}{ Sub Structural $1\left(\mathbf{X}_{1}, \mathbf{X}_{2}\right.$ Ke Y1) } \\
\hline $\begin{array}{l}\mathrm{X}_{1} \\
\left.\mathrm{Y} 1 \mathrm{X} \mathrm{X}_{1}\right)\end{array}$ & 0.410 & 3.506 & 0,000 & \multirow{2}{*}{0,538} \\
\hline $\begin{array}{l}\mathrm{X}_{2}(\mathrm{p} \mathrm{Y} 1 \\
\left.\mathrm{X}_{2}\right)\end{array}$ & 0.243 & 2.073 & 0,000 & \\
\hline \multicolumn{5}{|c|}{ Sub Structural $2\left(X_{1}, X_{2}\right.$ Ke Y2) } \\
\hline $\begin{array}{l}\mathrm{X}_{1} \\
\left(\mathrm{pYX}_{1}\right)\end{array}$ & 0.273 & 2.304 & 0,005 & \multirow{3}{*}{0,484} \\
\hline $\begin{array}{l}\mathrm{X}_{2} \\
\left(\mathrm{pYX} \mathrm{X}_{2}\right)\end{array}$ & 0.195 & 1.750 & 0,008 & \\
\hline $\mathrm{Y}(\mathrm{pYY})$ & 0.279 & 2.194 & 0,001 & \\
\hline
\end{tabular}

\section{Pembahasan}

Hasil penelitian menunjukkan terdapat pengaruh signifikan motivasi dan kepuasan terhadap disiplin pegawai pada Dinas Pertanian dan Ketahanan Pangan Kota Banjar. Motivasi yang tinggi yang ada pada diri pegawai merupakan suatu modal besar bagi suatu organisasi untuk dapat mewujudkan kepuasan kerja yang tinggi pula, hal ini tentunya merupakan harapan yang ingin dicapai oleh Pada Dinas Pertanian dan Ketahanan Pangan Kota Banjar. Dalam usahanya mewujudkan motivasi yang tinggi pada Dinas Pertanian dan Ketahanan Pangan Kota Banjar. Institusi dapat memilih cara memotivasi pegawai dengan tepat dan sesuai dengan situasi dan kondisi organisasi.
Handoko (2003: 252) mengatakan bahwa hubungan motivasi terhadap kepuasan kerja adalah sebagai berikut : "Motivasi yang ada pada diri seseorang merupakan kekuatan pendorong yang akan mewujudkan suatu perilaku guna mencapai tujuan kepuasan dirinya." Rivai (2008: 456) mengatakan bahwa hubungan motivasi terhadap kepuasan kerja adalah sebagai berikut : "Apabila individu termotivasi, mereka akan membuat pilihan yang positif untuk melakukan sesuatu, karena dapat memuaskan keinginan mereka."

Hasibuan (2008:100) mengemukakan baha pemberian motivasi bagi pegawai mempunyai beberapa tujuan dan bagi kelancaran usaha suatu organisasi. Adapun tujuan dari pemberian motivasi dapat diantaranya adalah meningkatkan kedisiplinan dan menurunkan tingkat absensi pegawai. Jadi jelas bahwa motivasi mempunyai pengaruh dalam upaya meningkatkan disiplin kerja pegawai. Pegawai yang motivasi kerjanya rendah cenderung akan membangun sikap yang destruktif sehingga upaya pendisiplinnya akan mengalami proses yang lebih rumit dan kompleks. Pegawai yang memiliki motivasi kerja yang tinggi akan membangun sikap yang konstruktrif sehingga pihak manajemen relatif akan lebih mudah untuk meningkatkan disiplin kerja pegawainya

Hasil penelitian menunjukkan terdapat pengaruh signifikan motivasi dan kepuasan terhadap kinerja pegawai pada Dinas Pertanian dan Ketahanan Pangan Kota Banjar. Motivasi merupakan rangsangan dari luar dalam bentuk benda atau bukan benda yang dapat menumbuhkan dorongan pada orang untuk memiliki, menikmati, menguasai atau mencapai benda atau bukan benda tersebut. Motivasi seseorang melakukan pekerjaan karena memiliki tujuan untuk memenuhi kebutuhan hidupnya. Seseorang akan merasakan kekhawatiran apabila 
kebutuhan hidupnya tidak tercapai sehingga hal tersebut akan mempengaruhi dalam diri individu untuk lebih meningkatkan motivasinya. Menurut Robbins (2002:174) motivasi merupakan keinginan untuk melakukan sesuatu dan menentukan kemampuan bertindak untuk memuaskan kebutuhan individu. Dengan segala kebutuhan tersebut, seseorang dituntut untuk bekerja lebih giat dan aktif dalam bekerja, karena dengan seseorang memiliki motivasi yang tinggi dalam melakukan pekerjaannya maka kinerja seseorang didalam organisasi akan meningkat dan target organisasi dapat tercapai. Hakim (2006:25) menyebutkan salah satu faktor yang mempengaruhi kinerja pegawai yaitu faktor motivasi, dimana motivasi merupakan kondisi yang menggerakan seseorang berusaha untuk mencapai tujuan atau mencapai hasil yang diinginkan. Latief (2012:2) mengemukakan dengan terbentuknya motivasi yang kuat, maka akan dapat membuahkan hasil atau kinerja yang baik sekaligus berkualitas dari pekerjaan yang dilaksanakannya.

Mangkunegara

(2009:61)

mengemukakan motivasi merupakan kondisi atau energi yang menggerakkan diri pegawai yang terarah atau tertuju untuk mencapai tujuan organisasi organisasi. Sikap mental pegawai yang positif terhadap situasi kerja itulah yang memperkuat motivasi kerjanya untuk mencapai kinerja yang maksismal. Hal ini berarti bahwa setiap peningkatan motivasi yang dimiliki oleh pegawai dalam melaksanakan pekerjaannya akan memberikan peningkatan terhadap kinerjanya.

Secara konsep kepuasan kerja memiliki hubungan dengan tingkat kinerja pekerja. Menurut konsep Value Theory, kepuasan kerja terjadi pada tingkatan di mana hasil pekerjaan diterima individu seperti yang diharapkan. Semakin banyak orang menerima hasil, akan semakin puas. Dengan terciptanya kepuasan kerja yang merupakan sikap positif yang dilakukan individual terhadap pekerjaan mereka, maka akan tercapainya kinerja individual tersebut (Wibowo, 2007:27). Selain itu dengan adanya kepuasan kerja dapat mengurangi turnover, dan mendorong individu Teori lain yang memperkuat hubungan kepuasan kerja dengan kinerja adalah teori dua faktor atau teori motivasi higiene, yang dikemukakan oleh seorang psikolog bernama Herzberg (1923-2000). Menurut teori ini, faktor motivasi (intrinsic factor) adalah: pekerjaan itu sendiri (the work it self), prestasi yang diraih (achievement), peluang untuk maju (advancement), pengakuan orang lain (ricognition), tanggung jawab (responsible). Faktor motivasi (intrinsic factor) merupakan faktor yang mendorong semangat guna menyenangi pekerjaan yang memungkinnya menggunakan kreativitas dan inovasinya (Robbins, dan Judge, 2007:174).

Selain itu hubungan positif antara kepuasan kerja dengan kinerja diperkuat oleh pendapat yang dikemukakan oleh Robbins dan Judge (2007:174), yang menyatakan bahwa organisasi yang mempunyai pegawai yang lebih puas cenderung lebih efektif bila dibandingkan organisasi yang mempunyai pegawai yang kurang puas.

Hasil penelitian menunjukkan terdapat pengaruh signifikan disiplin terhadap kinerja pegawai pada Dinas Pertanian dan Ketahanan Pangan Kota Banjar. Pada sebuah organisasi, pegawai merupakan tonggak utama dalam menjalankan organisasi tersebut. Maju tidaknya organisasi tergantung bagaimana pegawai tersebut berusaha agar organisasi tempat pegawai bekerja dapat mencapai tujuannya. Kinerja pegawai yang tinggi tercermin dalam disiplin kerja yang tinggi. Kinerja dipengaruhi oleh berbagai faktor baik yang berhubungan dengan tenaga kerja itu sendiri maupun faktor-faktor lain. Faktor-faktor tersebut antara lain disiplin kerja. Kinerja yang tinggi dapat dicapai jika didukung oleh para pegawai yang mempunyai semangat disiplin kerja yang tinggi dalam melaksanakan tugas dan kewajibannya. Disiplin kerja juga diartikan sebagai sikap ketaatan seseorang terhadap suatu aturan / ketentuan yang berlaku dalam organisasi yaitu menggabungkan diri dalam organisasi itu atas dasar adanya kesadaran dan keinsyafan bukan karena adanya unsur paksaan. Disiplin kerja dapat menumbuhkan kemampuan kerja dan bekerja sama, maka secara tidak langsung akan meningkatkan kinerja. Jadi apabila suatu organisasi mampu meningkatkan disiplin kerja, maka mereka akan memperoleh banyak keuntungan, karena pekerjaan akan terselesaikan dengan cepat, kerusakan akan dapat dikurangi, absensi akan dapat diperkecil.

Menurut pernyataan Sinungan (2007:148) "disiplin mendorong kinerja atau disiplin merupakan sarana penting untuk mencapai kinerja“. Dalam kondisi ini maka tindakan yang seharusnya organisasi lakukan meningkatkan kualitas organisasi misalnya 
adalah dengan peningkatan kinerja pegawai yaitu disiplin kerja. Kinerja pegawai dapat dilihat dari disiplin kerja yang dilakukan sehari-hari. Selain itu, dengan disiplin kerja yang tinggi dari pegawai, maka akan dapat merasakan hasil kerja yang selama ini ditekuni, dan akan mampu mencapai kinerja yang diharapkan organisasi.

\section{Kesimpulan}

1. Motivasi pegawai berpengaruh signifikan terhadap kinerja pegawai pada dimensi kebutuhan dan harapan. Artinya semakin baik motivasi pegawai maka kinerja pegawai akan semakin meningkat.

2. Kepuasan pegawai berpengaruh signifikan terhadap kinerja pada dimensi pekerjaan itu sendiri, upah, peluang promosi, pengawasan, kelompok kerja, kondisi kerja. Artinya semakin baik kepuasan pegawai maka kinerja pegawai akan semakin meningkat.

3. Disiplin kerja berpengaruh signifikan terhadap kinerja pada dimensi frekuensi kehadiran, tingkat kewaspadaan, ketaatan pada standar kerja, ketaatan pada peraturan kerja dan etika kerja. Artinya semakin baik kedisplinan maka kinerja pegawai akan semakin meningkat

4. Kinerja pegawai dipengaruhi oleh motivasi, kepusan dan disiplin. Artinya semakin baik motivasi, kepuasan dan disiplin maka kinerja pegawai akan semakin efektif. Dengan demikian maka hipotesis kerja dapat teruji kebenarannya karena $\mathrm{F}$ hitung > F tabel dengan $p$-value 0,00 .

\section{Saran}

1. Motivasi kerja pegawai berada pada kategori cukup baik dengan indikator terendah adalah harapan mengenai " ditempat bekerja tersedia sarana yang dibutuhkan, pimpinan memberikan reward bagi pegawai yang berprestasi, pimpinan membeda-bedakan bawahannya dalam bekerja, pimpinan memberikan kesempatan pada bawahan untuk mengaktualisasikan diri secara baik di kantor ". Tentu saja ini harus diperhatikan karena pegawai membutuhkan sarana yang lengkap dan penghargaan dari pimpinan.

2. Kepuasan kerja pegawai Dinas Pertanian dan Ketahanan Pangan Kota Banjar berada pada kategori cukup baik dengan indikator terendah adalah pengawasan. Hal ini perlu pengawasan lebih intensif dari pimpinan untuk memberikan penilaian atas hasil kerja pegawai.

3. Disiplin kerja pegawai Dinas Pertanian dan Ketahanan Pangan Kota Banjar berada pada kategori kurang baik dan terendah pada indikator etika kerja. Hal ini dapat diatasi dengan pemberian reward bagi pegaawai yang berprestasi dan pemberian sangsi bagi pegawai yang melanggar aturan organisasi

4. Kinerja pegawai Dinas Pertanian dan Ketahanan Pangan Kota Banjar berada pada kategori cukup baik dengan indikator terendah adalah perilaku termasuk kategori kurang baik. Hal ini dapat diperbaiki dengan pembinaan pegawai secara berkesinambungan dengan menekankan etos kerja yang baik.

\section{DAFTAR PUSTAKA}

Bejo, Siswanto. 2005. Manajemen Tenaga Kerja Indonesia pendekatan Administratif dan Operasional. Bumi Aksara. Jakarta.

Dessler, Gary. 2011. Manajemen Sumber Daya Manusia. Saduran Paramita Rahayu. Edisi kesepuluh. Indeks. Jakarta

George R. Terry ,2008. Prinsip-Prinsip Manajemen. (edisi bahasa Indonesia). PT. Bumi Aksara: Bandun

Gibson, Ivansevich, and Donelly, 2003, Organisasi: Perilaku, Struktur, Proses, Jilid 2, Binarupa Aksara, Jakarta.

Handayaningrat, Soewarno. (1995). Studi Ilmu Administrasi dan Manajemen. Jakarta: Ghalia Indonesia.

Handoko, T,H. 2001. Manajemen Peronalia dan Sumber Daya Manusia. Edisi 2.

Hasibuan, Malayu SP.2006. Manajemen Sumber Daya Manusia. Edisi Kesebelas. PT Bumi Aksara. Jakarta

Hasibuan, SP Malayu H, (2008), Organisasi dan Motivasi Dasar Peningkatan Produktivitas, Cetakan Kedua , Bumi Aksara, Jakarta.

Indrawijaya, I Adam, (2010), Teori Perilaku dan Budaya Organisasi, Cetakan Pertama PT. 